\title{
Pengimplementasian Karakter Nasionalis Siswa di Kelas VI SD
}

\author{
Chendi Maulana Baharudin Yusup ${ }^{1}$, Dinie Anggraeni Dewi ${ }^{2}$ \\ ${ }^{1,2}$ Pendidikan Guru Sekolah Dasar, Universitas Pendidikan Indonesia \\ Jl. Pendidikan No.15, Cibiru Wetan, Cileunyi, 40625, Bandung, Jawa Barat, Indonesia \\ Chendimaulana22@upi.edu
}

\begin{abstract}
This study aims to improve nationalist character education for students, especially in grade VI elementary schools. This type of research is qualitative research, which focuses on the implementation of naationalist character education in grade VI SD. Nationalist character education for elementary school children, especially in grade VI, is a process of fertilizing from an early age for them. In nationalist character education there are civic education subjects that teach the values contained in Pancasila and teach and educate students to become individuals who have habits of national character in their daily lives. Seeing the current condition of children, students have decreased in terms of implementing national character in their lives. Therefore, schools through civic education are expected to be able to train and educate students so that students have a nationalist attitude in their lives. A nationalist attitude is an understanding attitude that has cultural and regional harmony. They also have the same ideals and goals so that they feel the desire to defend their country, both from internal and external threats.
\end{abstract}

Key Word: Chaeacter education, Attitude of Nationalism

\begin{abstract}
Abstrak
Penelitian ini bertujuan untuk meningkatkan pendidikan karakter nasionalis pada siswa khususnya di kelas VI Sekolah Dasar. Jenis penelitian ini adalah penelitian kualitatif yang menitikberatkan pada pelaksanaan pendidikan karakter nasionalis di kelas VI SD. Pendidikan karakter nasionalis bagi anak sekolah dasar khususnya di kelas VI merupakan proses pembuahan sejak dini bagi mereka. Dalam pendidikan karakter nasionalis terdapat mata pelajaran PKn yang mengajarkan nilai-nilai yang terkandung dalam Pancasila dan mengajarkan serta mendidik peserta didik untuk menjadi individu yang memiliki kebiasaan berkarakter bangsa dalam kehidupan sehari-hari. Melihat kondisi anak saat ini, siswa mengalami penurunan dalam hal penerapan karakter bangsa dalam kehidupannya. Oleh karena itu, sekolah melalui pendidikan kewarganegaraan diharapkan mampu melatih dan mendidik siswa agar siswa memiliki sikap nasionalis dalam kehidupannya. Sikap nasionalis adalah sikap pengertian yang memiliki kerukunan budaya dan daerah. Mereka juga memiliki cita-cita dan tujuan yang sama sehingga mereka merasakan keinginan untuk mempertahankan negaranya, baik dari ancaman internal maupun eksternal.
\end{abstract}

Kata Kunci: Pendidikan Karakter, Sikap Nasionalisme

Copyright (C) 2021 Chendi Maulana Baharudin Yusup, Dinie Anggraeni Dewi

$\triangle$ Corresponding author: Chendi Maulana Baharudin Yusup

Email Address: Chendimaulana22@upi.edu (Jl. Pendidikan No.15, Cibiru, Wetan, Cileunyi, Bandung)

Received 22 March 2020, Accepted 24 April 2020, Published 30 April 2021

\section{PENDAHULUAN}

Siswa adalah harapan orang tua juga umumnya banyak orang, terutama bangsa dan negara untuk meneruskan ekspetasi bangsa yang besar ini. Sebagai siswa dituntut untuk senantiasa memiliki karakter nasionalis, juga bisa mengimplenetasikannya dalam kehidupan sehari-harinya. Siswa harus bisa memahami dengan baik dan benar mengenai sikap karakter nasional sebagai bangsa dan warga negara yang peduli atas Negara Kesatuan Republik Indonesia, karena suatu negara juga ditentukan oleh karakter nasionalis yang dimiliki oleh 
setiap warga negaranya. Pendidikan karakter nasionalis memiliki peranan yang sangat signipikan untuk generasi penerus yang bermutu dalam dunia pendidikan. Pendidkan adalah sesuatu yang sangat penting bagi anak-anak, pendidikan ini yang menjadi tolak ukur suatu warga negara di negara tersebut, pendidikan bukan hanya sekedar belajar dan menuntut ilmu akan tetapi lebih ke pendidikan karakter siswa.

Sekolah adalah tempat yang dapat membentuk karakter nasionalis terhadap siswa, sekolah juga bukan hanya tempat untuk menuntut ilmu pengetahuan saja, tetapi tempat yang paling terpenting dalam pengimplementasian karakter nasionalis terhadap anak-anak. Dimana anak mendapatkan pemahaman dan pengertian karakter di sekolah. Pendidikan karakter di sekolah bukan hanya pendidikan karakter yang mencakup karakter religius, gotong royong, integritas, mandiri, tetapi juga mencakup pada karakter nasionalisme. Pendidikan karakter nasionalisme diajarkan pada anak-anak untuk belajar menempatkan kepentingan bangsa dan negara di atas kepentingan diri dan kelompoknya. Dalam simulasinya, di sekolah mereka rutin melaksanakan upacara bendera di hari Senin, apel pagi, menyanyikan lagu Indonesia Raya dan lagu nasional lainnya, untuk secara tidak langsung menanamkan jiwa nasionalis.

Sikap nasionalis itu sendiri bisa ditunjukan dengan mengapresiasi budaya Indonesia, menjaga kekayaan budaya bangsa, rela berkorban, berprestasi, cinta tanah air, menjaga lingkungan, taat hukum, disiplin, menghormati keberagaman budaya, suku, dan agama. Disamping itu butuh juga pelajaran lainnya untuh lebih menumbuhkan rasa nasionalis pada anak. Di sekolah kegiatan ini disimulasikan dengan masuk dalam kegiatan intra-kulikuler, atau kegiatan belajar mengajar sehari-hari dijam pelajaran. Tak hanya cukup sampai disitu, kegiatan ko-kulikuler dan ekstrakulikuler pun punya peran juga. Contohnya anak dapat mengikuti kegiatan pramuka, dan paskibra. Pendidikan yang tepat adalah pendidikan yang berorientasi membangun karakter siswa yang diperlukan dalam rangka pengembangan sikapsikap mulia, ,bertanggung jawab, disiplin, berbudi pekerti luhur, mandiri, namun melihat krisis karakter yang terjadi membuktikan bahwa sistem pendidikan belum membentuk sumber daya manusia yang diharapkan. Hal ini ditegaskan (Sudrajat, A. 2011) kurang berhasilnya sistem pendidikan membentuk sumber daya manusia dengan karakter yang tanggung jawab, berbudi pekerti luhur, disiplin dan mandiri, terjadi di semua lembaga pendidikan baik negeri maupun swasta.

Karakter yang dimiliki siswa berdasarkan nilai-nilai, keyakinan, kebiasaan-kebiasaan yang berlaku di masyarakat dan bangsa Indonesia maka pendidikan karakter melalui budaya sekolah diarahkan pada upaya membentuk kepribadian siswa yang baik. pendekatan budaya sekolah adalah pengelolaan pendidikan karakter.Artinya karakter siswa dapat dibentuk melalui budaya sekolah yang kondusif.Budaya sekolah yang kondusif adalah keseluruhan latar fisik lingkungan, suasana sekolah, rasa, sifat dan iklim sekolah yang secra produktif mampu 
memberikan pengalaman baik bagi tumbuh kembangnya kecakapan hidup siswa yang diharapkan. Pendidikan karakter dan pendidikan kecakapan hidup siswa akan efektif bilamana disemaikan dalam budaya sekolah.

\section{Pendidikan Karakter}

Kata character berasal dari bahasa Yunani charassein, yang berarti to engrave (melukis, menggambar), seperti orang yang melukis kertas, memahat batu atau metal. Berakar dari pengertian yang seperti itu, character kemudian diartikan sebagai tanda atau ciri yang khusus, dan karenanya melahirkan sutu pandangan bahwa karakter adalah 'pola perilaku yang bersifat individual, keadaan moral seseorang'. Setelah melewati tahap anak-anak, seseorang memiliki karakter, cara yang dapat diramalkan bahwa karakter seseorang berkaitan dengan perilaku yang ada di sekitar dirinya (Kevin Ryan, 1999:5). Karakter yang baik berkaitan dengan mengetahui yang baik (knowing the good), mencintai yang baik (loving the good), dan melakukan yang baik (acting the good). Ketiga ideal ini satu sama lain sangat berkaitan. Seseorang lahir dalam keadaan bodoh, dorongan-dorongan primitif yang ada dalam dirinya kemungkinan dapat memerintahkan atau menguasai akal sehatnya. Maka, efek yang mengiringi pola pengasuhan dan pendidikan seseorang akan dapat mengarahkan kecenderungan, perasaan, dan nafsu besar menjadi beriringan secara harmoni atas bimbingan akal dan juga ajaran agama.

Secara sederhana, pendidikan karakter dapat didefinisikan sebagai segala usaha yang dapat dilakukan untuk mempengaruhi karakter siswa. Tetapi, untuk mengetahui pengertian yang tepat, dapat dikemukakan di sini definisi pendidikan karakter yang disampaikan oleh Thomas Lickona. Lickona (1991) menyatakan bahwa pendidikan karakter adalah suatu usaha yang disengaja untuk membantu seseorang sehingga ia dapat memahami, memperhatikan, dan melakukan nilai-nilai etika yang inti. Bertitik tolak dari definisi tersebut, ketika kita berpikir tentang jenis karakter yang ingin kita bangun pada diri para siswa, jelaslah bahwa ketika itu kita menghendaki agar mereka mampu memahami nilai-nilai tersebut, memperhatikan secara lebih mendalam mengenai benarnya nilai-nilai itu, dan kemudian melakukan apa yang diyakininya itu, sekalipun harus menghadapi tantangan dan tekanan baik dari luar maupun dari dalam dirinya. Dengan kata lain mereka meliliki 'kesadaran untuk memaksa diri' melakukan nilai-nilai itu.

\section{Sikap Nasionalisme}

Nasionalisme adalah perasaan satu sebagai suatu bangsa, satu dengan seluruh warga yang ada dalam masyarakat. Nasionalisme bangsa Indonesia melahirkan ideologi negara, yaitu Pancasila. Dalam ideologi Pancasila terdapat lima prinsip nilai yang bersifat dasar (staat fundamental norms) dan menjadi ajaran dasar yang digunakan sebagai pedoman bagi seluruh warga bangsa Indonesia, baik dalam tataran individu maupun kelompok (Rohman, N. 2018). Hal tersebut didukung oleh pendapat yang menyatakan bahwa nasionalisme yang digunakan 
sebagai alat pemersatu oleh para pendiri bangsa ini adalah nasionalisme sebagai bentuk perwujudan dari nilai-nilai Pancasila, yaitu nasionalisme yang mentauladani sifat-sifat Tuhan, cinta akan keadilan, egaliter, dan menghargai hak asasi manusia.

Rasa nasionalisme yang berdasarkan nilai-nilai Pancasila akan mewujudkan nasionalisme yang luas, yaitu mencintai bangsa sendiri tetapi masih menghargai bangsa lain. Nilai yang terkandung dalam nasionalisme Indonesia ialah persatuan dan kesatuan, perasaan senasib, toleransi, kekeluargaan, tanggung jawab, sopan santun dan gotong royong (Supriyoko, Ki. 2001). Pendapat senada juga diungkapkan Lailatus Sa ${ }^{e e}$ diyah (2012: 48), yaitu nilai-nilai pendidikan karakter yang juga berpengaruh pada pembentukan sikap nasionalisme antara lain nasionalisme, tanggung jawab, disiplin, toleransi, kerja keras dan peduli sosial.Bentuk dari nilai nasionalisme yaitu memiliki: toleransi, kedisiplinan, tanggung jawab, kerja keras, sopan santun, sikap gotong royong, dan peduli sosial.

Berangkat dari temuan masalah tersebut, maka dapat digambarkan bahwa guru perlu melakukan inovasi pembelajaran yang mendidik dan menanamkan nilai-nilai karakter terutama nilai nassionalisme.Guru hendaknya lebih kreatif dan inovatif dalam penggunaan model pembelajaran penanaman karakter yang menekankan pada moral knowing, moral feeling dan moral action dalam pembelajaran.Beberapa srategi pembelajaran yang dapat diterapkan guru untuk meningkatkan karakter nasionalisme yaitu Living Values Education Program (LVEP) dan story telling.

Selanjutnya (Hambali. 2015) menyatakan bahwa proses pembentukan karakter nasionalis pada siswa didukung oleh nilai-nilai dasar yang dipraktekkan dalam lingkungan keluarga. Nilai-nilai tersebut kemudian diperkuat di sekolah melalui lingkungan kelas, lingkungan sekolah dan kegiatan ekstra kurikuler. Langkah tersebut sesuai dengan teori pembelajaran sosial (Social Learning Theory) yang sering disebut teori observational learning. Teori ini dikemukakan oleh Albert Bandura, Kardi, S., (1997), seorang psikolog pada Universitas Stamford Amerika Serikat. Menurutnya pembelajaran berdasarkan tiga asumsi, yaitu: Bahwa individu melakukan pembelajaran dengan meniru apa yang ada di lingkungannya, terutama perilaku-perilaku orang lain. Perilaku orang lain yang ditiru disebut sebagai perilaku model atau perilaku contoh. Apabila peniruan itu memperoleh penguatan, maka perilaku yang ditiru itu akan menjadi perilaku dirinya. Proses pembelajaran menurut proses kognitif individu dan kcakapan dalam membuat keputusan, Terdapat hubungan yang erat antara pelajar dengan lingkungannya. Pembelajaran terjadi dalam keterkaitan antara tiga pihak yaitu lingkungan, perilaku dan faktor-faktor pribadi, Hasil pembelajaran adalah berupa kode perilaku visual dan verbal yang diwujudkan dalam perilaku sehari-hari. 


\section{METODE}

Dalam penelitian ini digunakan motodologi penelitian dengan penelitian kualitatif, yang memiliki karakteristik alami (natural setting) sebagai sumber data langsung, deskriptif, di samping hasil proses lebih dipentingkan, analisis dalam penelitian kualitatif cenderung dilakukan secara induktif dan makna merupakan hal yang essensial (Moleong, 2000: 3). Wawancara adalah percakapan dengan maksud tertentu oleh dua pihak, yaitu pewancara (inteviewer) sebagai pengaju/pemberi pertanyaan dan yang diwawancarai (interview) sebagai pemberi jawaban atas penyataan itu Dalam hal ini, jenis penelitian yang digunakan adalah studi kasus, yaitu suatu deskripsi intensif dan analisis fenomena tertentu atau satuan sosial seperti individu, kelompok, institusi atau masyarakat. Studi kasus dapat digunakan secara tepat dalam banyak bidang. Di samping itu merupakan penyelidikan secara rinci satu setting, satu subyek tunggal, satu kumpulan dokumen atau satu kejadian tertentu. Ciri khas penelitian kualitatif tidak dapat dipisahkan dari pengamatan berperanserta, namun peranan penelitilah yang menentukan keseluruhan skenarionya (Moleong, 2002: 117). Untuk itu dalam penelitian ini, peneliti bertindak sebagai instrumen kunci, partisipan penuh, sekaligus pengumpul data sedangkan instrumen yang lain sebagai penunjang. Misalnya Kepala Sekolah, Waka. Kurikulum, Guru Mapel, Siswa.

Dalam penelitian ini, peneliti memilih narasumber terhadap guru kelas VI Sekolah Dasar Negri Hanura Kota Bandung. Dalam halnya pengimplementasian karakter nasionalis siswa dalam kehidupan sehari-harinya masih belum dapat dikatkan sempurna, karena masih banyak siswa-siwa yang tidak mengimplementasikan poin-poin nasionalisme dalam kehidupan sehari-harinya.

Tahap-tahap penelitian dalam penelitian ini ada tiga tahapan dan ditambah dengan tahap terakhir dari penelitian yaitu tahap penulisan laporan hasil penelitian. Tahap-tahap penelitian tersebut adalah:

1. Tahap pra lapangan, yang meliputi: menyusun rancangan penelitian, memilih lapangan penelititan, menilai keadaan lapangan, memilih dan memenfaatkan informasi. Kegiatan penelitian dengan cara mewawancari narasumber yaitu guru di SD Negri Hanura Kota Bandung, terkait pengimplementasian karakter nasionalis siswa kelas VI SD.

2. Tahap pekerjaan lapangan, yang meliputi: memahami latar belakang penelitian dan persiapan diri, memasuki lapangan dan berperan serta sambil mengumpulkan data,

3. Tahap analisis data, yang meliputi: analisis selama dan setelah pengumpulan data,

4. Tahap penulisan hasil laporan penelitian.

Sumber data utama dalam penelitian ini adalah kata-kata hasil dari wawancara dengan guru, Data disini terbagi menjadi satu, yaitu data primer. Data primer adalah data yang didapatkan secara langsung/diambil dari objek, yaitu wawancara langsung dengan guru. Dalam penelitian kualitatif, teknik pengumpulan data lebih banyak pada observasi, 
wawancara, dan dokumentasi . Bagi peneliti kualitatif fenomena dapat dimengerti maknanya secara baik apabila dilakukan interaksi dengan subyek melalui wawancara mendalam dan diobservasi pada latar penelitian, di mana fenomena tersebut berlangsung dan di samping itu untuk melengkapi data diperlukan dokumentasi (tentang bahan yang ditulis oleh subyek atau tentang subyek). Teknik analisis data dalam kasus ini menggunakan analisis data kualitatif . Mengikuti konsep yang diberikan Miles \& Huberman dan Spradley. Miles dan Huberman, mengemukakan bahwa aktivitas dalam analisis data kualitatif dilakukan secara interaktif dan berlangsung secara terus-menerus pada setiap tahapan penelitian sehingga sampai tuntas, dan datanya sampai jenuh. Aktifitas dalam analisis data, meliputi data reduction yaitu mereduksi data dalam konteks penelitian yang dimaksud adalah merangkum, memilih hal-hal yang pokok, menfokuskan pada hal-hal yang penting, membuat katagori. Dengan demikian data yang telah direduksiakan memberikan gambaran yang lebih jelas dan mempermudah peneliti untuk melakukan pengumpuklan data selanjutnya, data display dan conclusion yaitu adalah mendisplaykan data atau menyajikan data ke dalam pola yang dilakukan dalam bentuk uraian singkat, bagan, grafik, matrik, network dan chart. Bila pola-pola yang ditemukan telah didukung oleh data selama penelitian, maka pola tersebut sudah menjadi pola yang baku yang selanjutnya akan didisplaykan pada laporan akhir penelitian. Teknik Triangulasi adalah teknik pemeriksaan keabsahan data yang memanfaatkan sesuatu yang lain di luar data itu untuk keperluan pengecekan atau sebagai pembanding terhadap data itu. Ada empat macam triangulasi sebagai teknik pemeriksaan yang memanfaatkan penggunaan: sumber, metode, penyidik, dan teori .

Dalam penelitian ini peneliti menggunakan teknik triangulasi sumber. Artinya, peneliti membandingkan dan mengecek kembali derajat kepercayaan informasi yang diperoleh dengan cara:

a. Membandingkan isi perkataan narasumber satu dengan yang lainnya, hasil dari wawancara terhadap guru SD Negri Hanura, Kota Bandung,

b. Membandingkan apa yang dikatakan orang di depan umum dengan apa yang dikatakan secara pribadi.

c. Membandingkan hasil wawancara dengan isi suatu dokumen yang berkaitandengan pengimplementasian karakter nasionalis pada anak SD Kelas VI.

\section{HASIL DAN PEMBAHASAN}

Setelah dilaksanakan wawancara dengan narasumber yaitu salah satu guru dari SD Negri Hanura Kota Bandung, bahwasanya dapat dikatakah anak-anak belum semuanya mampu untuk mengimplementasikan apa yang dimaksud dengan karakter nasionalis, dimana meraka belum benar-benar sadar terhadap apa itu karakter nasionalis dalam kehidupan sehari-harinya. Itu juga disebabkan karena kurangnya kesadaran dari guru, dan juga orang 
tua untuk bisa mengarahkan anak-anaknya ke jalur pengimplementasian karakter nasionalisnya disetiap aktifitas yang anak-anak jalankan di mana pun mereka berada. Hal tersebut merupakan suatu tugas rumah tersendiri untuk pemerintah termasuk juga guru di sekolahsekolah supaya benar-benar lebih bisa memberikan pemahaman kembali, mengenai apa yang harus di lakukan anak-anak untuk bisa mempunyai karakter nasionalisme dan juga bisa mengimplementasikan dari karakternya tersebut. Hal lain yang menyebabkan kenapa anakanak tidak bisa menerapkan atau mengimplementasikan karakter nasionalis dalam kehidupannya adalah karena mulai masuknya budaya-budaya dari luar yang tidak tersaring dan diketahui anak, dan bahkan jadi budaya tersendiri bagi bangsa Indonesia yang membuat hal itu melupakan jati diri atau budaya bangsa kita sendiri. Bahkan kebanyakan anak-anak sekarang lebih mengenal budaya negara tetangga atau negara lain untuk digemarinya, karena terkesan modern dan juga kekinian, tak sedikit dari anak-anak bangsa ini juga yang dalam kehidupan sehari-harinya menggunakkan bahasa asing supaya terlihat keren.

Tidak mudah memang memberikan pemahaman atau juga pematerian tentang karakter nasionalis terhadap anak, apalagi masih di kelas VI SD, butuh kesabaran dan juga kekreatifan dari masing-masing guru untuk bisa memberikan anak-anak akan pengertian dan juga pemahamannya, untuk bisa di implementasikan oleh anak-anak kelas VI SD, para guru harus terus tak ada henti-hentinya untuk mengingatkan supaya anak bisa membiasakan diri atau mengimplementasikan dari pemahamannya terkait karakter nasionalisme yang ada dalam diri setiap anak. Karena pastinya dalam diri setiap anak sudah terdapat karakter nasionalisnya tetapi yang menjadi permasalahannya adalah anak kurang dalam pengimplementasiannyatersebut. Perlunya juga kerjasama antara orang tua, dan guru untuk bisa mempermudah membentuk karakter nasionalis yang sudah terbentuk dalam diri setiap anak-anak supaya bisa ditonjolkan lagi dengan cara pengamalannya dalam kehidupan sehari hari, supaya dengan karakter nasional yang melekat pada diri anak bisa menunjukan jati diri bangsa dan negara certita kita ini, yaitu Negara Kesatuan Republik Indonesia.

Poin yang terpenting jangan samapi juga para guru-guru, atau orang tua tidak mencontohkan pengimplementasian rasa nasionalis cinta terhadap bangsa dan negara, karena dengan kita memberikan contoh langsung terhadap anak itu merupakan pembelajaran secara tidak langsung yang guru-guru, dan orang tua berikan terhadap anak-anaknya untuk menjadikan modal awal dalam pengimplementasian karakter nasionalisme pada anak-anak khusunya yang sedang di bahas yaitu anak-anak kelas VI SD. Karakter nasionalisme yang terbentuk pada siswa kelas VI SD berikutnya adalah sikap peduli terhadapa satu dengan yang lainnya artinya saling tolong menolong. Sikap inilah yang dijadian sebagai landasan dan bingkai yang menjadikan kekeluargaan nasionalis dalam kehidupan berbangsa dan bernegara, tidak memiliki sifat egois dan merasa bisa hidup sendiri. Karakter ini mengatur bagaimana siswa harus bersikap dalam hidup sehari-hari, khususnya dalam kehidupan 
Pengimplementasian Karakter Nasionalis Siswa di Kelas VI SD, Chendi Maulana Baharudin Yusup, Dinie Anggraeni Dewi

beragama dan bermasyarakat. Tujuan akhirnya adalah kesadaran akan pluralisme atau keragaman, yang saling melengkapi bukan membawa kepada perpecahan.

\section{KESIMPULAN}

Dari hasil wawancara yang telah dilaksanakan bersama guru di salah satun sekolah dasar Negri Hanura Kota Bandung, bahwasanya masih banyak kekurangan pemahaman anak-anak terkait sikap nasionalisme, dimana anak tidak paham betul dengan sikap nasionalisme yang seharusnya bisa mereka pahami di kelas VI SD untuk bekalnya dalam mengimplementasikan di kehidupan sehari-hari. Sebagian juga anak-anak sudah memahami dan memiliki sikap nasionalis yang melekat dalam dirinya, tetapi masih belum bisa anaktersebut untuk mengimplementasikannya dikarenakan beberapa hal, mulai dari kurangnya guru dalam upaya mengingatkan kembali anak supaya bisa menerapkan hal tersebut dalam aktifitas sehari-harinya, juga kurangnya pengawasan dari orangtua anak-anak dalam pergaulannya, sehingga anak bergaul tanpa harus memikirkan sikap nasionalisme dalam dirinya tersebut, yang menyebabkan anak berbuat apa yang menurutnya senang.

Sebuah penyesalan besar jika memang anak-anak tidak bisa menerapkan atau mengimplementasikan karakter nasionalis dalam dirinya di kehidupan sehari-harinya, karena itu merupakan suatu kegagalan tersendiri bagi pendidikan di Negara Kesatuan Republik Indonesia. Dimana karakter nasional harus benar-benar bisa diterapkan dilingkungan masyarakat, tanpa terkecuali anak kelas V1 SD. Dengan karakter nasionalis inilah jadi diri bangsa Indonesia bisa terlihat didalam maupun luar negara, dengan pengimplementasian yang dilakukan oleh anak-anak SD kelas VI akan menjadi nilai tambahan dan juga poin tersendiri untuk kedepannya bagi pendidikan karakter nasionalis bangsa tercinta ini.

Negara Kesatuan Republik Indonesia bisa dipandang sebagai negara yang maju apabila seluruh warga negaranyamelaksanakanpengimplementasian karakter nasional dalam kehidupan berbangsa, dan bernegara. Kita akan dilihat oleh negara-negara lain dan juga ditakuti dengan ciri khas karakter nasional yang ada didalam setiap individu-individu setiap wargan negaranya.

\section{UCAPAN TERIMAKASIH}

Terima kasih saya ucapkan kepada bapak agus muhidin dan bapak aep selaku pengajar anak siswa kelas IV di SD NEGERI HANURA, dan tak lupa kepada kakak-kakak editor yang sudah membimbing saya sampai saya bisa lolos seleksi dalam mem pubhlish artikel saya. Tanpa dukungan dan dorongan dari kalian tidak mungkin saya bisa menyelesaikan tugas ini dengan baik.

\section{REFERENSI}

Hambali. 2015. Students Reaction Towards Nation Characters Education and the Impacts on The Practice of Nationalist Characters. Journal of Applied Sciences. 15 (9). ISSN 1812-5654 Asian Network for Scientific Information.

Kardi, S. 1997. Pengajaran Langsung. Surabaya: Unesa University Press 
Lickona, Thomas. 1991. Educating for Character: How Our School Can Teach Respect and Responsibility. New York: Bantam Books

Moleong, Lexi J. 2002. Metodologi Penelitian Kualitatif. Bandung: PT. Remaja Rosdakarya.

Rohman, N. 2018. Manajemen Penguatan Pendidikan Karakter Siswa Di sekolah Dasar (Studi Di SD UT Bumi Kartini Jepara).

Ryan, Kevin dan Karen E. Bohlin. 1999. Building Character in Schools: Practical Ways to Bring Moral Instruction to Life. San Francisco: JOSSEY-BASS A Wiley Imprint

Sa'diyah, Lailatus. 2012. Peranan Guru Sejarah dan Pendidikan Karakter dalam Pembentukan Sikap Nasionalisme Siswa. Skripsi. Semarang: Unnes.

Sudrajat, A. 2011. Mengapa pendidikan karakter?. Jurnal Pendidikan Karakter, 1(1).

Supriyoko, Ki. 2001. Menggugat Nilai-Nilai Nasionalisme. jurnal.amikom.ac.id/index.php/Koma/article/viewFile/3007/pdf_734 